\title{
Vascular Access Device Complications
}

National Cancer Institute

\section{Source}

National Cancer Institute. Vascular Access Device Complications. NCI Thesaurus. Code C71746.

Difficulties related to an apparatus used to gain access to arteries and veins. 